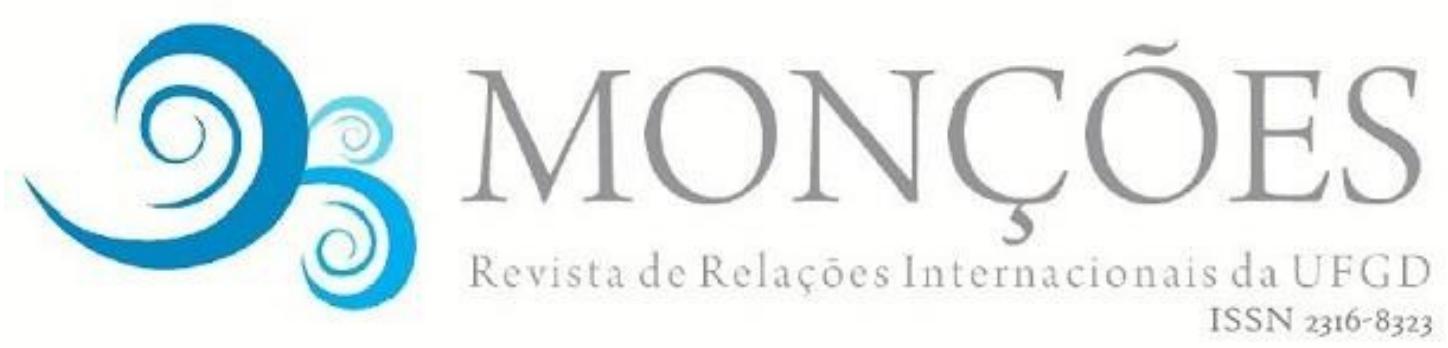

\title{
DIREITOS HUMANOS E REFUGIADOS: RELAÇÕES ENTRE REGIMES INTERNACIONAIS CONSTRUÍDOS NO SISTEMA ONU
}

\author{
JULIA BERTINO MOREIRA \\ Professora do Bacharelado de Relações Internacionais, \\ do Programa de Pós-Graduação em Ciências Humanas e Sociais \\ e membro da Cátedra Sérgio Vieira de Mello da UFABC; \\ Doutora em Ciência Política pela UNICAMP
}

\author{
JANINE HADASSA OLIVEIRA MARQUES DE BORBA \\ Mestranda em Diplomacia e Relações Internacionais \\ pela Universidade da Bretanha Ocidental (França) e \\ Graduada em Relações Internacionais pela UFABC
}

\begin{abstract}
RESUMO: O presente artigo busca analisar as relações tecidas entre o regime internacional de direitos humanos e o regime internacional relativo aos refugiados - ambos estruturados no contexto do pós-Segunda Guerra Mundial -, lançando luz, sobretudo, para a influência ocidental na construção da definição de refugiado cunhada pela Convenção Relativa ao Estatuto dos Refugiados de 1951. A proposta é ressaltar os termos notadamente marcados por uma perspectiva individualista e liberal dos direitos civis e políticos, a qual já estava presente na Declaração Universal dos Direitos Humanos de 1948, reverberando na elaboração da Convenção de 1951. Sustenta-se, nesse sentido, que a categorização da perseguição individualizada por motivos de nacionalidade, religião, raça, filiação a determinado grupo social ou opinião política privilegia direitos civis e políticos, tornando-os elementos centrais no regime internacional relativo aos refugiados - em detrimento a outros direitos reconhecidos como econômicos, sociais e culturais. A argumentação desenvolvida no texto se ampara em revisão bibliográfica da literatura especializada na área de estudos sobre refugiados, pesquisa documental sobre a Declaração Universal, a Convenção de 1951 e outros instrumentos jurídicos correlatos, além de artigos de relevância acadêmica e dados disponibilizados pela Organização das Nações Unidas.
\end{abstract}

PALAVRAS-CHAVE: direitos humanos, refugiados, regimes internacionais.

\section{HUMAN RIGHTS AND REFUGEES: RELATIONS CONSTRUCTED BETWEEN BOTH INTERNATIONAL REGIMES WHITHIN THE UN SYSTEM}

\begin{abstract}
This article aims to analyze the relationship between the international human rights regime and the international refugee regime - both structured during the post-Second World War context -, particularly shedding light on the Western influence on the construction of the refugee definition designed by the 1951 Convention Relating to the Status of Refugees. The proposal is to emphasize the aspects regarding an individualistic and liberal perspective of civil and political rights.
\end{abstract}


Those were already presented in the 1948 Universal Declaration of Human Rights and echoed in the 1951 Convention. The categorization of individualized persecution on grounds of nationality, religion, race, affiliation to a particular social group or political opinion privileged civil and political rights which emerged as central elements within the international refugee regime. Therefore, the economic, social and cultural rights were treated as secondary rights. The main argument is based on literature review of the specialized literature in refugee studies, documental research on the Declaration, Convention and subsequent treaties, as well as academic articles and available data of the United Nations.

KEYWORDS: human rights, refugees, international regimes.

\section{Introdução}

Os refugiados constituem uma categoria específica das migrações internacionais. Diante de conflitos intra ou interestatais, por motivos étnicos, religiosos, políticos, de regimes repressivos e de outras situações de violência e violações de direitos humanos em seus países de origem, esses indivíduos sofrem ameaças ou efetivas perseguições, sendo forçados a cruzar as fronteiras em busca da proteção de outro Estado, com o objetivo primordial de resguardar suas vidas, liberdade e segurança. Atores internos e internacionais, estatais e não-estatais sobretudo os países de origem e receptores, organizações internacionais e Organizações Não-Governamentais - estão envolvidos na gestão dessa questão de alcance global.

Nota-se uma relação intrínseca entre os temas dos refugiados e dos direitos humanos. Vale dizer: o Estado de origem violou ou ameaçou violar direitos fundamentais como a vida, a segurança, as liberdades civis (locomoção, expressão, opinião política e religião) de seus cidadãos ou de estrangeiros que se encontravam no território nacional. Ou, então, foi omisso, permitindo que grupos não-estatais o fizessem. Ambas as temáticas foram tratadas historicamente a partir da constituição de regimes internacionais no bojo do sistema ONU - como se verá a seguir.

Seguindo Ruggie e Kratochwil ${ }^{1}$, em suas visões construtivistas, regimes internacionais são concebidos como entendimentos intersubjetivos constituídos entre atores diversos, que passam a ser compartilhados e difundidos

\footnotetext{
${ }^{1}$ RUGGIE, John Gerard; KRATOCHWIL, Fridrich von. Epistemologia, ontologia y el estudio de los regimes internacionales. Relaciones Internacionales, Madrid, v. 12, p. 171-191, oct. 2009.
} 
internacionalmente. Nesse sentido, os autores destacam a importância de se olhar para significados atribuídos no processo histórico de constituição dos regimes. Propomo-nos a compreender mais a fundo aspectos cruciais tanto da Declaração Universal dos Direitos Humanos (DUDH) de 1948, quanto da Convenção Relativa ao Estatuto dos Refugiados de 1951 - ambas centrais na estruturação dos respectivos regimes internacionais de direitos humanos e refugiados -, tecendo relações entre eles.

O artigo objetiva, portanto, resgatar o processo histórico que antecedeu a adoção da DUDH de 1948 e da Convenção de 1951, pautando a discussão pelo contexto do pós-Segunda Guerra Mundial e da incipiente Guerra Fria. Pretendeu-se explorar como a definição clássica da Convenção de 1951 reverberou a disputa entre potências no âmbito da ONU, resultando na prevalência da perspectiva ocidental nos dispositivos trazidos pela Convenção. Buscou-se, a partir daí, apontar os sentidos pelos quais o regime de direitos humanos impactou o regime de refugiados, reforçando significados hierarquizantes entre direitos reconhecidos como fundamentais à pessoa humana. A metodologia de pesquisa se pautou por revisar a bibliografia especializada e por documentos jurídicos essenciais referentes às temáticas estudadas. Igualmente foram levantados dados disponibilizados pela Organização das Nações Unidas e pelo Alto Comissariado das Nações Unidas para Refugiados para embasar a análise.

\section{Regime Internacional de Direitos Humanos}

Sobretudo após a Segunda Guerra Mundial, diante das atrocidades cometidas por regimes totalitários, em especial o nazista, passou-se a reconhecer o Estado - representado por seus agentes burocráticos - , embora com atribuições de resguardar e efetivar os direitos mais basilares de seus cidadãos, como potencial violador desses direitos fundamentais. Houve, assim, uma intensa mobilização internacional que ensejou a criação de um regime internacional de direitos humanos em 1948, preconizado com a celebração da Declaração Universal dos Direitos do Homem pela Organização das Nações Unidas (ONU), esta instituída formalmente 
em $1945^{2}$. Aportavam-se o direito internacional e a democracia liberal como pilares fundantes de uma nova era voltada a reduzir perdas humanas e mobilizar todas as nações rumo à proteção da dignidade humana e ao respeito aos direitos individuais ${ }^{3}$.

A Declaração Universal dos Direitos Humanos (DUDH) iniciou, assim, um processo conhecido como "justicialização" dos direitos humanos, porque logrou definir de maneira mais clara o que se entendia por direitos essenciais inerentes a toda pessoa humana. Apontou diretrizes que, apesar da soberania estatal, deveriam pairar sobre todas as jurisdições, atribuindo como responsabilidade dos Estados acompanhar o tratamento dado aos indivíduos inclusive em outras jurisdições. Estabelecia, com isso, um novo paradigma para o qual todas as sociedades deveriam caminhar ${ }^{4}$. Duas concepções foram determinantes, então, para a configuração deste novo regime: o reconhecimento de limites postos à soberania estatal e do indivíduo como sujeito de Direito Internacional, alçando-se a titular de direitos e deveres não somente na esfera nacional, como na internacional ${ }^{5}$.

Cabia à Comissão de Direitos Humanos da ONU, criada em 1946, conduzir a elaboração da Declaração Universal de Direitos Humanos, a qual seria aprovada dois anos depois. Os direitos previstos neste documento jurídico foram delineados da seguinte forma: do artigo $3^{\circ}$ ao 21 encontravam-se os direitos civis e políticos; ao passo que, do artigo 22 ao 28 , os direitos econômicos, sociais e culturais ${ }^{6}$. De um lado, resguardavam-se a vida, a nacionalidade, o asilo, o não recebimento de tratamentos ou punições cruéis, desumanos e degradantes, a não discriminação racial, étnica, religiosa, além de garantias legais vinculadas à ampla defesa e ao devido processo legal e as liberdades de pensamento, opinião, religião, movimento, reunião e associação pacífica, bem como o sufrágio. De outro, asseguravam-se o trabalho, a remuneração justa, a alimentação, o bem-estar, a seguridade social, a

\footnotetext{
${ }^{2}$ ALVES, José Augusto Lindgren. Direitos Humanos como Tema Global. São Paulo: Perspectiva, 1995.

${ }^{3}$ COMPARATO, Fabio Konder. A Afirmação Histórica dos Direitos Humanos. São Paulo: Saraiva, 2013.

${ }^{4}$ PIOVESAN, Flavia. Direitos Humanos e o Direito Constitucional Internacional. São Paulo: Saraiva, 2013.

${ }^{5}$ ARENDT, Hannah. As origens do totalitarismo. São Paulo: Companhia das Letras, 1989.

REIS, Rossana Rocha. Construindo Fronteiras: políticas de imigração na França e nos Estados Unidos (1980-1988). Tese de doutorado FFLCH/ USP, São Paulo, 2002.

${ }^{6}$ ALVES, op. cit., 1995.
} 
educação e a participação na vida cultural da comunidade ${ }^{7}$.

Apesar do aparente caráter conciliatório, o processo de elaboração da Declaração foi permeado por acirradas divergências quanto à definição do que entraria no rol de direitos humanos, devido à forte influência das potências vitoriosas da Segunda Guerra Mundial ${ }^{8}$. Duas posições evidenciaram a disputa de ideias no centro da Comissão de Direitos Humanos da ONU, já no limiar da Guerra Fria. O bloco ocidental manifestava maior interesse na propagação dos direitos individuais civis e políticos, o que de fato motivou sua categorização como direitos "ocidentais". De sua parte, o bloco soviético realizou esforços em prol da defesa de direitos econômicos e sociais, considerados igualmente relevantes para a proteção da dignidade humana e da realização do ser humano em um contexto de coletividade. Assim, as concepções defendidas foram duramente marcadas pelas disputas de poder, além da percepção de ameaça (ou caráter de imposição de limites) às soberanias nacionais dos Estados-nação. Não obstante este embate, a Declaração logrou ser aprovada com 48 votos a favor e 8 abstenções (dentre as quais, a União Soviética) $)^{9}$.

Vale lembrar que a Declaração não possui caráter vinculante, ou seja, nasceu desprovida de força jurídica em relação aos Estados signatários. Contudo, a sua importância é reconhecida por ter firmado as bases para posteriores pactos $e$ convenções com caráter vinculante. A literatura especializada se divide, assim, entre aqueles que atribuem o peso de tratado internacional à Declaração e outros que expressam a premência de sua natureza consuetudinária ${ }^{10}$.

Adotada a DUDH, a Comissão de Direitos Humanos concentrou esforços para elaboração de um pacto único de direitos humanos, haja vista a necessidade de melhor se especificar os direitos previstos pela declaração e vincular juridicamente os Estados-parte à sua observância. Porém, esta pretensão não foi possível de se alcançar, dada a já citada polarização ideológica em torno de quais direitos deveriam ser primordialmente protegidos. O bloco ocidental destacava 0 caráter "primário" da noção individualista de direitos, argumentando que direitos

${ }^{7}$ DECLARAÇÃO UNIVERSAL DE DIREITOS HUMANOS, 1948.

ALVES, op. cit, 1995.

${ }^{8}$ ALVES, op. cit, 1995.

${ }^{9}$ ALVES, op. cit, 1995.

${ }^{10}$ COMPARATO, Fabio Konder. A Afirmação Histórica dos Direitos Humanos. São Paulo: Saraiva, 2013. 
civis e políticos poderiam ser monitorados por serem de aplicação imediata. Daí serem necessários dois instrumentos: um referente aos direitos civis e políticos e outro, aos direitos econômicos e sociais. Por sua vez, o bloco soviético, percebendo que a hierarquização de direitos culminaria na prioridade conferida aos direitos civis e políticos, defendia um único instrumento capaz de abranger todos os direitos sem distinção (posição esta originalmente sustentada pela $\mathrm{CDH}$ ).

A proposta ocidental despontou como vitoriosa em 1951, quando a Assembleia Geral determinou a elaboração de dois pactos distintos. Tanto prevaleceu a perspectiva ocidental que ficou cunhada expressamente a interpretação de que os direitos econômicos e sociais se caracterizariam pela realização progressiva. Isto equivalia a dizer que: enquanto os direitos civis e políticos seriam plenamente concretizáveis, os direitos econômicos, sociais, culturais demandariam mais ações por parte dos Estados, em um caráter contínuo, para que fossem implementados.

O Pacto Internacional de Direitos Econômicos, Sociais e Culturais e o Pacto Internacional de Direitos Civis e Políticos foram aprovados por unanimidade em 10 de dezembro de 1966 e somente entraram em vigor na década posterior, após atingirem o número de ratificações exigidas - portanto, com grande lapso temporal em relação à $D U D H$.

\section{Pacto Internacional de Direitos Econômicos, Sociais e Culturais de 1966}

\author{
Direito ao trabalho e à \\ remuneração justa \\ De formar e de associar-se a \\ sindicatos \\ Direito a um nível de vida \\ adequado \\ Direito à educação
}

Direito à participação na vida cultural da comunidade

\section{Pacto Internacional de} Direitos Civis e Políticos de 1966

Fonte: ALVES, 2003, p. 51-52 (elaboração a partir do autor). 
A implementação dos direitos reconhecidos pelo Pacto de Direitos Econômicos, Sociais e Culturais foi estabelecida mediante monitoramento do Conselho Econômico e Social das Nações Unidas (ECOSOC) sobre os relatórios submetidos pelos Estados-parte. O ECOSOC é formado por dezoito peritos que têm a função de avaliar estes relatórios em sessão pública. Este processo é formalizado dentro do Comitê para Direitos Econômicos, Sociais e Culturais, criado em 1987. Por outro lado, a implementação do Pacto de Direitos Civis e Políticos é de responsabilidade do Comitê de Direitos Humanos ${ }^{11}$, também composto por dezoito membros eleitos. O processo se inicia com o recebimento dos relatórios pelo Secretário Geral das Nações Unidas que posteriormente os transmite para 0 Comitê. Os relatórios, todavia, devem indicar as medidas adotadas para dar efeito aos direitos reconhecidos e apontar os progressos realizados nesse sentido. Assim, os relatórios são analisados pelo Comitê, o qual os transmite novamente aos Estados-parte com recomendações. Por fim, o Comitê reporta os relatórios ao ECOSOC.

Outros mecanismos podem ser destacados como estruturantes para 0 processo de acompanhamento do cumprimento de direitos humanos em âmbito local. Os regimes regionais europeu, interamericano e africano visaram dar autonomia às sociedades sobre a fiscalização sobre eventuais violações, além de operaram como garantia adicional quando o Estado se mostra omisso na proteção de tais direitos.

O primeiro regime regional implementado foi o europeu, tendo como base a Convenção de Direitos Humanos elaborada pelo Conselho Europeu em 1949, adotada no ano seguinte e com entrada em vigor em 1953, prevendo essencialmente direitos civis e políticos. A Carta Social Europeia, que tratou dos direitos econômicos, sociais e culturais, entrou em vigor apenas em 1965 e passou por um processo de revisão em 1996. A partir de 1998, houve uma mudança profunda neste regime, permitindo a indivíduos, grupos e ONGs peticionar

\footnotetext{
${ }^{11}$ Não à toa o órgão que monitora o cumprimento de direitos civis e políticos foi nomeado Comitê de Direitos Humanos. Assim vingava o entendimento de que direitos humanos seriam basilarmente direitos civis e políticos. Os direitos econômicos, sociais, culturais, considerados secundários ou decorrentes dos primeiros, caberiam a outro órgão - este sim referido pelos direitos de sua atribuição: Comitê dos Direitos Econômicos, Sociais e Culturais (grifos nossos).
} 
diretamente à Corte Europeia de Direitos Humanos, que igualmente recebe comunicações interestatais. $O$ regime interamericano foi o segundo a ser criado e faz parte da Organização dos Estados Americanos. A Convenção Americana de Direitos Humanos - também conhecida como Pacto de San José de Costa Rica foi adotada em 1969 e entrou em vigor em 1978. Tal qual como ocorreu com o regime europeu, a Convenção Americana estabeleceu apenas direitos civis e políticos, ficando a cargo do Protocolo de San Salvador de 1999 versar sobre os direitos econômicos, sociais e culturais. A Comissão Interamericana recebe petições individuais ou feitas por grupos e ONGs, além de comunicações interestatais. Diferentemente do atual regime europeu, o indivíduo e coletividades não possuem acesso direito à Corte Interamericana (somente a Comissão e os Estados-parte podem acioná-la). Por fim, o regime africano foi constituído mais tardiamente, com a Carta Africana dos Direitos Humanos e dos Povos adotada em 1981 no bojo da então Organização de Unidade Africana (atualmente União Africana) e em vigor desde 1986. A Carta, com caráter mais coletivista de direitos e contemplando tanto os civis e políticos como os econômicos, sociais e culturais, criou tão-somente a Comissão Africana de Direitos Humanos, com o objetivo de analisar petições de indivíduos e ONGs, além de comunicações interestatais. Apenas em 1998 adotouse um Protocolo à Carta com a finalidade de estabelecer uma Corte Africana de Direitos Humanos. Por ser mais recente, até 2014, a Corte havia decidido sobre 22 casos de violações de direitos ${ }^{12}$.

O regime europeu, não apenas por ter sido pioneiro, constituído no contexto do pós-guerra, é visto de modo geral pela literatura da área como o mais consolidado, destacando-se pela possibilidade de instituir sanções aos Estados e indivíduos violadores, além de ter sido o primeiro a permitir que as vítimas pudessem encaminhar petições individuais denunciando violações a seus direitos, como já pontuado ${ }^{13}$.

Retomando o sistema ONU, importa citar que, em 2006, houve uma reforma significativa, objetivando uma pujante modificação na estrutura do regime

\footnotetext{
${ }^{12}$ Para maiores informações, ver: PIOVESAN, Flávia. Direitos Humanos e Justiça Internacional. São Paulo: Saraiva, 2012.

${ }^{13}$ PIOVESAN, op. cit., 2012.
} 
internacional de direitos humanos. A Comissão de Direitos Humanos foi substituída pelo Conselho de Direitos Humanos, após um longo período de estagnação atribuída a acusações de ineficiência, politização e ausência de transparência por parte da instituição. A mudança institucional, incluindo a nova nomenclatura, culminou na invenção de um novo procedimento de avaliação global dos Estados perante suas situações domésticas em matéria de direitos humanos: a Revisão Periódica Universal ${ }^{14}$. Além disso, ao longo das décadas de sua existência, um conjunto de agências especializadas foram criadas dentro do sistema ONU para monitorar os direitos previstos pela DUDH, melhor especificados nos dois Pactos Internacionais e progressivamente expandidos mediante a adoção de diversas convenções. A Convenção Relativa ao Estatuto de Refugiados de 1951 é um dos documentos que apontam nesse sentido ao demarcar a estruturação de um novo regime internacional, específico em matéria de refúgio, adotado na mesma periodização em que se deu a Declaração Universal.

\section{Regime internacional relativo aos refugiados}

O tema dos refugiados ganhou destaque internacional sobretudo a partir do pós-guerra, devido à intensa movimentação provocada pela Segunda Guerra Mundial (1939-1945), com milhões de pessoas deslocadas de seus países de origem no interior da Europa ${ }^{15}$. Esse cenário de deslocamentos no continente europeu causou preocupação aos então países aliados (EUA, URSS, França e Reino Unido), especialmente no tocante à estabilidade e segurança regionais ${ }^{16}$. $O$ tema dos refugiados se alçou, assim, a uma questão internacional de relevo particularmente no mesmo contexto histórico em que o tema dos direitos humanos teve destaque.

\footnotetext{
${ }^{14}$ SHORT, Katherine. Da Comissão ao Conselho: a Organização das Nações Unidas conseguiu ou não criar um organismo de direitos humanos confiável? SUR Revista Internacional de Direitos Humanos, v. 5, n.9, 2008.

${ }^{15}$ HOBSBAWN, Eric. Era dos extremos: o breve século XX: 1914-1991. São Paulo: Companhia das Letras, 1995.

${ }^{16}$ ACNUR, op. cit., 2000.
} 
Interessa notar, portanto, a estreita relação tecida entre ambas as temáticas. A DUDH previu, em seu artigo 14 (1), o direito de procurar e gozar asilo ${ }^{17}$ a toda pessoa vítima de perseguição. No entanto, o direito de o indivíduo perseguido em seu país de origem buscar asilo - ao transpor fronteiras, deslocar-se para outro país e solicitar-Ihe proteção - não se confundia com o direito ao asilo, ou seja, à concessão desta proteção pelo país de acolhida ${ }^{18}$. Dessa forma, a Declaração resguardava $\mathrm{o}$ direito de $\mathrm{o}$ indivíduo procurar asilo, mas não a obrigação dos Estados de concedê-lo - da mesma forma como ocorreu com a Convenção Relativa ao Estatuto dos Refugiados de 1951. A concessão do asilo constituía um ato fundamentalmente soberano do Estado, intrinsecamente relacionado com outra atribuição estatal: o controle territorial e de suas fronteiras.

A constituição do regime internacional aos refugiados surgia com base em auto-interesses mútuos perseguidos pelos Estados ocidentais, que buscaram a cooperação internacional, fundada na reciprocidade, para administrar esses movimentos migratórios. Mas, tal qual o regime de direitos humanos, também foi fortemente permeada por diferentes visões acerca dessa questão e, principalmente, pelos interesses e pelas ideias que orientavam o embate altamente politizado entre as duas superpotências (URSS e EUA) no marco da Guerra Fria ${ }^{19}$.

A criação do Alto Comissariado das Nações Unidas para os Refugiados (ACNUR) ensejou um forte debate em torno do mandato dessa organização, no bojo

\footnotetext{
17 Importante destacar que o termo asilo carrega o significado de "não-violência". Na literatura internacional, asilo e refúgio são empregados de forma intercambiante (em Inglês, respectivamente: asylum e refuge). Contudo, na região da América Latina, referem-se a institutos jurídicos e políticos diferenciados, previstos em instrumentos específicos. Asilo é utilizado de forma mais ampla, contemplando o asilo político em modalidades distintas (territorial e diplomático), ao passo que refúgio se traduz na definição contida pela Convenção de 1951 e, posteriormente, em outros instrumentos regionais, em especial a Declaração de Cartagena de 1984, como explicado adiante. Para maiores detalhes, consultar, entre outros: MOREIRA, Julia Bertino; SALA, José Blanes. Migrações forçadas: categorização em torno de sujeitos migrantes. In: JUBILUT, Liliana Lyra; FRINHANI, Fernanda de Magalhães Dias; LOPES, Rachel de Oliveira (Org.). Migrantes Forçad@s: conceitos e contextos. Boa Vista: Editora da UFRR, 2018. P. 15-42.

${ }^{18}$ ANDRADE, José Henrique Fischel de. Breve reconstituição histórica da tradição que culminou na proteção internacional dos refugiados. In: ARAUJO, N.; ALMEIDA, G. A. de (Coord.). O Direito Internacional dos Refugiados: uma perspectiva brasileira. Rio de Janeiro: Renovar. 2001. P 99-125.

${ }_{19}$ MILLER, Mark J. International migration in post-cold war international relations. GHOSH, Bimal. Managing migration: time for a new international regime? Oxford: Oxford university press, 2000. P. 2747. BETTS, Alexander. Protection by persuasion: international cooperation in the refugee regime. Ithaca: Cornell University Press, 2009b. SALOMON, Kim. Refugees in the cold war: toward a new international refugee regime in the early postwar era. Lund: Lund University Press; Bromley: Chartwell-Bratt, 1991.
} 
da ONU. A maioria dos países da Europa Ocidental defendia uma agência forte e independente, capaz de angariar fundos, visto que os deslocamentos de refugiados atingiam em grande medida o continente europeu. Os EUA, preocupados com a questão orçamentária, propunham um organismo temporário que exigisse pouco financiamento e não pudesse receber contribuições. A URSS, por sua vez, empenhou-se em boicotar as negociações, pois não tinha interesse em apoiar a constituição de uma agência especializada dedicada a refugiados que, naquele contexto, eram majoritariamente dissidentes políticos do Leste Europeu ${ }^{20}$.

Apesar das divergências entre esses Estados, o ACNUR foi estabelecido em dezembro de 1950, passando a funcionar no início do ano seguinte, com a missão de prover proteção internacional aos refugiados e voltando-se, naquele momento, para a atuação em prol dos refugiados europeus, o que refletia o seu caráter essencialmente eurocêntrico ${ }^{21}$. O Estatuto da agência da ONU para os refugiados definia seu trabalho como apolítico, social e humanitário. Porém, como vários estudiosos colocam, essa caracterização é, sem dúvida, questionável ${ }^{22}$.

Além da criação de uma agência especializada para refugiados, era preciso definir juridicamente o que se entenderia pelo termo refugiado, delimitando o seu significado por meio de um instrumento internacional: a Convenção Relativa ao Estatuto dos Refugiados de 1951. A categoria dos refugiados foi, então, construída a partir de um processo de debate entre os atores envolvidos na temática, em que pesaram visões e motivações diferenciadas.

O debate em torno do significado e dos contornos que se dariam ao termo refugiado cindiu, de forma geral, os representantes dos países que estiveram presentes no evento em duas posições distintas. A primeira, denominada universalista, sustentava que o termo refugiado deveria abarcar pessoas de todas e

20 MOREIRA, Julia Bertino. Política em relação aos refugiados no Brasil (1947-2010). Tese (Doutorado em Ciência Política) - Instituto de Filosofia e Ciências Humanas, Campinas: UNICAMP, 2012.

${ }_{21}$ ACNUR, op. cit., 2000; LOESCHER, Gil. Beyond Charity: international cooperation and the global refugee crisis. New York: Oxford University Press, 1996.

${ }_{22}$ Para essa discussão, ver, entre outros: Loescher, 1996; Hathaway, 1991; Hyndman, 2000. 
quaisquer origens. A segunda, chamada de corrente europeísta (ou eurocêntrica), advogava que apenas os europeus deveriam ser reconhecidos como refugiados ${ }^{23}$.

O primeiro grupo, liderado pelo representante do Reino Unido, com apoio dos países do BENELUX, da Escandinávia e do Alto Comissário para os Refugiados, argumentava que o problema dos refugiados no mundo não significaria um grave encargo para os países europeus e que uma Convenção elaborada no seio da ONU deveria garantir direitos aos refugiados de onde quer que fossem. A delegação do Reino Unido foi quem mais defendeu a concepção universalista, pretendendo uma definição de refugiado o mais ampla possível, sem qualquer tipo de limitação. Inclinava-se no sentido de "apoiar e compreender as aspirações idealistas do Alto Comissário"24. Há que se destacar, todavia, que o Reino Unido, por questões geográficas, não estava exposto a um grande fluxo de refugiados, como outros países europeus ocidentais ${ }^{25}$.

O segundo grupo, sob a liderança dos representantes da França e dos EUA, com o apoio também da Itália, entre outros países, apresentava como justificativa para sua posição o fato de já acolherem um grande número de refugiados e, caso a definição fosse muito abrangente, não teriam condições financeiras de abrigar um contingente ainda maior. Diante disso, somente poderiam se comprometer com as obrigações contidas na Convenção se fosse adotada uma definição limitada de

${ }^{23}$ ARQUIVO DO ITAMARATY, CONSULADO GERAL DOS ESTADOS UNIDOS DO BRASIL Relatório sobre a Conferência de plenipotenciários para o Estatuto dos Refugiados e Apátridas. Genebra, 18 ago. 1951. ACNUR, Conference of plenipotentiaries on the status of refugees and stateless persons: summary record of the twenty-first meeting. 1970. Disponível em: $<$ http://www.unhcr.ch/cgi-bin/textis/vtx/print?tbl=PROTECTION\&id=3ae68cdec $>$. Acesso em: 5 abr. 2005._. Conference of plenipotentiaries on the status of refugee and stateless persons: summary record of the twenty-second meeting. 1970. Disponível em: <http://www.unhcr.ch/cgibin/textis/vtx/print?tbl=PROTECTION\&id=3ae68cde10 . . Acesso em: 5 abr. 2005. Conference of plenipotentiaries on the status of refugee and stateless persons: summary record of the twenty-third meeting. $1970 . \quad$ Disponível em: $\quad$ http://www.unhcr.ch/cgibin/textis/vtx/print?tbl=PROTECTION\&id=3ae68cda10>. Acesso em: 5 abr. 2005.

${ }^{24}$ ARQUIVO DO ITAMARATY, op. cit., 1951.

${ }^{25}$ SALOMON, op. cit., 1991; ACNUR, Conference of plenipotentiaries on the status of refugees and stateless persons: summary record of the twenty-first meeting. 1970. Disponível em: <http://www.unhcr.ch/cgi-bin/textis/vtx/print?tbl=PROTECTION\&id=3ae68cdec>. Acesso em: $5 \mathrm{abr}$. 2005._. Conference of plenipotentiaries on the status of refugee and stateless persons: summary record of the twenty-second meeting. 1970. Disponível em: <http://www.unhcr.ch/cgibin/textis/vtx/print?tbl=PROTECTION\&id=3ae68cde10 >. Acesso em: 5 abr. 2005. Conference of plenipotentiaries on the status of refugee and stateless persons: summary record of the twenty-third meeting.

1970.

Disponível em: $<$ http://www.unhcr.ch/cgibin/textis/vtx/print?tbl=PROTECTION\&id=3ae68cda10>. Acesso em: 5 abr. 2005. 
refugiado. Outro argumento levantado se fundava no fato de que os refugiados existentes no mundo àquela época tinham origem europeia e que, assim, tratava-se de um problema europeu. Posicionavam-se, com isso, a favor de uma definição restrita à data dos eventos que ocorreram na Europa, a partir do início do funcionamento do ACNUR ${ }^{26}$.

O consenso a que se chegou nesse processo de debate se resumiu a atrelar a interpretação do termo a uma decisão estatal dada no momento de adesão ao instrumento - o que reforçava a perspectiva soberana estadocêntrica. Seguindo Salomon, a Convenção favoreceu um caminho médio, criando dois tipos de Estados contratantes: os que cobriam refugiados do mundo todo e os que cobriam somente a Europa $^{27}$.

A partir da definição construída pela Convenção, cunhada como "clássica", considerava-se como refugiado qualquer pessoa

\begin{abstract}
que, em consequência dos acontecimentos ocorridos antes de $1^{\circ}$ de janeiro de 1951, e receando com razão ser perseguida em virtude da sua raça, religião, nacionalidade, filiação em certo grupo social ou das suas opiniões políticas, se encontre fora do país de que tem a nacionalidade e não possa ou, em virtude daquele receio, não queira pedir a proteção daquele país; ou que, se não tiver nacionalidade e estiver fora do país no qual tinha a sua residência habitual após aqueles acontecimentos, não possa ou, em virtude do dito receio, a ele não queira voltar ${ }^{28}$.
\end{abstract}

Esta definição tratava o refúgio como um estatuto sobretudo de caráter individual, embora pudesse ser concedido também a grupos, especialmente em função da perseguição decorrente de filiação em certo grupo social. Também estendia a categoria de refugiado aos apátridas, pessoas não detentoras de nacionalidade, que tiveram de se deslocar em função dos eventos políticos que atingiram o país de residência. Após o reconhecimento como refugiado, contudo, a

\footnotetext{
${ }^{26}$ ACNUR, Conference of plenipotentiaries on the status of refugees and stateless persons: summary record of the twenty-first meeting. 1970. Disponível em: <http://www.unhcr.ch/cgi$\mathrm{bin} / \mathrm{textis} / \mathrm{vtx} /$ print?tbl=PROTECTION\&id=3ae68cdec $>$. Acesso em: 5 abr. 2005._. . Conference of plenipotentiaries on the status of refugee and stateless persons: summary record of the twentysecond meeting. 1970 . Disponível em: <http://www.unhcr.ch/cgibin/textis/vtx/print?tbl=PROTECTION\&id=3ae68cde10 $>$. Acesso em: 5 abr. 2005. . Conference of plenipotentiaries on the status of refugee and stateless persons: summary record of the twenty-third 1970. Disponível em: bin/textis/vtx/print?tbl=PROTECTION\&id=3ae68cda10>. Acesso em: 5 abr. 2005.

27 SALOMON, op. cit., 1991.

${ }^{28}$ ACNUR, Convenção Relativa ao Estatuto dos Refugiados. In: . Manual de procedimentos e critérios a aplicar para determinar o estatuto de refugiado. Lisboa: ACNUR, 1996. p. 61.
} 
pessoa poderia deixar de ter o estatuto, seja por vontade e iniciativa própria, ou em decorrência de uma mudança na situação do país de origem, cessando as circunstâncias que a levaram a fugir (chamadas de cláusulas de cessação previstas artigo $1^{\circ} \mathrm{C}$ da Convenção) ${ }^{29}$.

Além da possibilidade de cessação, havia previsão de exclusão, daqueles que não poderiam ser incluídos, portanto, na categoria de refugiado (denominadas de cláusulas de exclusão previstas no artigo $1^{\circ} \mathrm{D}, \mathrm{E}, \mathrm{F}$ da Convenção) ${ }^{30}$, isso porque já gozavam de proteção internacional de outro organismo da ONU, cometeram crime contra a paz, de guerra ou contra a humanidade, grave crime de direito comum fora do país receptor antes do pedido de refúgio ou, por fim, praticaram atos contrários aos objetivos e princípios da ONU. Assim, nem todos eram considerados necessitados ou merecedores de refúgio.

A definição ainda trazia, em seu bojo, uma limitação temporal, que restringia sua aplicação aos "acontecimentos ocorridos antes de 1ํ de janeiro de 1951". Estes acontecimentos poderiam ser interpretados de duas formas: como aqueles que ocorreram na Europa ou como aqueles que ocorreram na Europa ou fora desta. Com base na primeira interpretação, somente seriam reconhecidos como refugiados pessoas de origem europeia (o que foi denominado de reserva geográfica); ao passo que, pela segunda, pessoas de todos os cantos do mundo. Caberia ao Estado-parte delimitar o alcance que daria ao termo, mas poderia alterá-lo posteriormente por meio de uma notificação dirigida ao Secretário Geral da $\mathrm{ONU}^{31}$.

Ancorada em duas limitações, uma de caráter temporal e outra geográfica, a definição de refugiado nascia fadada à inaplicabilidade aos eventos posteriores de novos deslocamentos de refugiados. Como destaca Conley, estas duas restrições contidas na Convenção refletiam a concepção de que os refugiados constituíam um problema temporário do continente europeu, que havia sido gerado pela guerra, e que seria resolvido logo após esta ${ }^{32}$. Porém, para Salomon, as potências ocidentais

\footnotetext{
${ }^{29}$ Ibidem, p. 62.

${ }^{30}$ Ibidem, p. 63.

31 ACNUR, op. cit., 1996.

${ }^{32}$ CONLEY, Marshall. The institutional framework of refugee law and political forces. In: MAHONEY, Kathleen; MAHONEY, Paul (Ed.) Human Rights in twenty-first century: a global challenge. Dordrecht: Kluwer Academic Publications, 1993. p. 629-643.
} 
tinham conhecimento de que se tratava de uma questão de caráter permanente e que certamente haveria novos movimentos migratórios no futuro, mas não pretendiam comprometer-se com maiores responsabilidades, sobretudo em relação a recursos financeiros a serem aportados para lidar com essa população ${ }^{33}$. Hathaway salienta que essas limitações eram estratégicas e motivadas por interesses políticos dos países ocidentais ${ }^{34}$.

O próprio emprego do termo perseguição no cerne da definição de refugiado é apontado por Loescher como parte da estratégia ocidental, ao incluir refugiados políticos basicamente da Europa de Leste e estigmatizar os países comunistas como perseguidores. Também era uma forma apropriada de lidar com as chamadas minorias étnicas e religiosas no continente ${ }^{35}$. Nesse sentido, Matas enfatiza que a Convenção de 1951 foi originalmente designada pelos países ocidentais para prover refúgio aos anticomunistas que fugiam do Leste Europeu após a Segunda Guerra Mundia ${ }^{36}$. Portanto, desde sua gênese, possuía forte caráter liberal, ocidental e eurocentrado, embora pretendesse lançar a categoria jurídica "refugiado" como sendo universal. Seguia, assim, como exposto aqui, a mesma perspectiva que a Declaração, visto que esta carregava a universalidade apenas em seu nome, ao enfatizar uma visão particular sobre a natureza dos direitos humanos, a qual se julgava de alcance global.

É importante ressaltar que o acolhimento de refugiados no contexto do pósguerra atendia a interesses de diversas ordens dos países ocidentais, incluindo o líder do bloco. Havia interesses de cunho político-ideológico e geoestratégico, uma vez que se denunciava a fuga de pessoas de países governados por regimes socialistas, com 0 intuito de descreditar 0 bloco soviético e os ideais que 0 sustentavam. Ainda, se faziam presentes interesses de caráter econômico, apesar do receio com encargos financeiros e descontentamento da população local, já que a Europa atravessava um período de reconstrução e necessitava de mão de obra

\footnotetext{
${ }^{33}$ SALOMON, op. cit., 1991.

${ }^{34}$ HATHAWAY, op. cit., 1991.

${ }^{35}$ LOESCHER, Gil. Beyond Charity: international cooperation and the global refugee crisis. New York: Oxford University Press, 1996.

${ }_{36}$ MATAS, David. A history of the politics of refugee protection. In: MAHONEY, Kathleen; Mahoney, Paul. (Ed.). Human Rights in the Twenty-First Century: a global challenge. Dordrecht: Kluwer Academic Publishers, 1993. p. 619-628.
} 
barata e abundante para suprir seu mercado de trabalho. E, por fim, não havia um acirrado problema cultural, devido à proximidade em termos identitários entre refugiados europeus (do Leste) e as comunidades receptoras (seja de países também europeus, porém do Ocidente, seja de ex-colônias, como EUA, Canadá e Austrália). Essas motivações combinadas fizeram com que grande parte dos países ocidentais se comprometesse com o regime internacional de refugiados da ONU. ${ }^{37}$

A base desse regime estava calcada no princípio de não devolução (nonrefoulement), estabelecido pela Convenção em seu artigo 33 (1), que proibia os Estados-parte de devolver os refugiados para as fronteiras dos territórios onde suas vidas ou liberdades estivessem ameaçadas, em virtude de sua raça, religião, nacionalidade, filiação em certo grupo social ou opiniões políticas ${ }^{38}$. Esse princípio constituía simultaneamente um direito individual e um dever estatal. Tratava-se de uma garantia aos indivíduos que não eram nacionais nem cidadãos, portanto, não portadores de direitos em relação ao Estado-nação de acolhimento, já que este deveria autorizar a permanência dos refugiados em seu território até que pudessem ingressar com segurança em outro Estado. Com isso, o regime de refugiados, assim como os dos direitos humanos, reconheceu a existência do indivíduo no cenário internacional, ao torná-lo titular de direitos. Ao mesmo tempo, impunha certos limites à soberania estatal, ao constranger, de alguma forma, a autonomia decisória do Estado em relação ao controle de suas fronteiras. Por outro lado, o regime recémformado não estabeleceu o dever dos Estados de acolher refugiados em seus territórios, o que reforçava a lógica da soberania estatal e dos interesses subjacentes a ela. Da mesma maneira, não proveu ao indivíduo o direito de ter o estatuto de refugiado reconhecido ${ }^{39}$.

Além do princípio de não devolução, a Convenção estabeleceu, no artigo 31 (1), o princípio da não aplicação de sanção no caso de entrada irregular, segundo o

\footnotetext{
${ }^{37}$ REIS, Rossana Rocha; MOREIRA, Julia Bertino. Regime internacional para refugiados: mudanças e desafios. Revista Sociologia Política, v. 18, n. 37, 2010.

${ }^{38}$ ACNUR, op. cit., 1996, p. 74.

${ }^{39}$ REIS, op. cit., 2002. ALEINIKOFF, Alexander. State-centered refugee Law: from resettlement to containment. In: DANIEL, E. Valentine; KNUDSEN, John Chr (Ed.). Mistrusting refugees. Berkeley; Los Angeles; London: University of California Press, 1995. p. 257-278. DAUVERGNE, Catherine. Challenges to sovereignty: migration laws for the 21st century. New issues in refugee research n. 92. Geneva: UNHCR, 2003.
} 
qual os indivíduos que fugiram de países onde suas vidas e liberdades estavam ameaçadas e que entraram ou permaneceram de maneira irregular em outros Estados não deveriam ser punidos ${ }^{40}$. Outro princípio previsto foi o da possibilidade de apresentação de recurso após decisão desfavorável ao refúgio, conforme disposto no artigo $32(2)^{41}$. Por fim, o princípio da reunião familiar, embora não previsto no texto da Convenção, mas consignado na Ata Final da Conferência ${ }^{42}$ que a adotou, enfatiza a importância dos membros da família do refugiado estarem juntos, reunidos no mesmo país de recepção.

A Convenção igualmente conferiu aos refugiados, preconizando especialmente tratamento igualitário aos nacionais em termos de direitos referentes a: propriedade, não discriminação, liberdade religiosa, associação (sem fins políticos), acesso à justiça e assistência judiciária, trabalho assalariado, educação pública, alojamento, assistência social, liberdade de movimento e documentos (papeis) no país de acolhida (conforme previstos nos artigos $3^{\circ}$ a 28).

Segundo Jaeger, a Convenção, contudo, apresentava lacunas para além das limitações geográfica e temporal, que se referiam à recepção dos solicitantes de refúgio e ao procedimento que seria adotado para concessão de refúgio. A primeira pode ser atribuída ao fato de que muitos países participantes da conferência ${ }^{43}$ já possuíam experiência com a recepção de solicitantes de refúgio, inclusive administrando grande número deles no período entre-guerras. A segunda também se baseava em uma justificativa histórica, já que, durante a atuação da Liga das Nações, as soluções dadas pelos Estados europeus para o reconhecimento do estatuto de refugiado foram tidas como satisfatórias, por meio da cooperação entre os governos e as comunidades locais, muitas vezes com apoio da organização internacional encarregada ${ }^{44}$. Todavia, a ausência de provisões referentes aos dois

\footnotetext{
${ }^{40}$ ACNUR, op. cit., 1996, p. 73.

${ }^{41}$ Ibidem, p. 73.

42 Ibidem, p. 45.

${ }^{43}$ Representantes de vinte e seis países estiveram presentes na conferência: Austrália, Áustria, Bélgica, Brasil, Canadá, Colômbia, Dinamarca, Egito, EUA, França, Grécia, Holanda, Iraque, Israel, Itália, lugoslávia, Luxemburgo, Mônaco, Noruega, Reino Unido e Irlanda do Norte, República Federal da Alemanha, Suécia, Suíça (cuja delegação também representou Liechtenstein), Turquia e Venezuela. Além destes, Cuba e Irã foram representados por observadores. ACNUR, op. cit., 1996.

${ }^{44}$ JAEGER, Gilbert. Opening keynote address: the refugee Convention at fifty. In: VAN SELM, Joanne; KAMANGA, Khoti; MORRISON, John; NADI, Aninia; SPOLJAR-VRZINA, Sanja; VAN
} 
aspectos mencionados ensejou discrepâncias entre os Estados signatários em relação à determinação do estatuto de refugiado e ao tratamento conferido aos refugiados pelos países receptores ${ }^{45}$.

Como bem coloca Loescher, os Estados interpretam as normas do Direito Internacional dos Refugiados conforme seus próprios interesses, principalmente por inexistir uma autoridade supranacional para compeli-los a cumpri-las ${ }^{46}$. Ao relegar inteiramente aos Estados soberanos a decisão sobre quem deve ser reconhecido como refugiado, para Aleinikoff, a Convenção falhou em resolver a gestão da questão dos refugiados na esfera global ${ }^{47}$. Não foram poucos os $\operatorname{casos}^{48} \mathrm{em}$ que Estados-parte desrespeitaram o princípio básico do regime, o da não devolução de refugiados para territórios em que suas vidas, liberdade e segurança pudessem estar em risco. O regime de refugiados apresentava, portanto, falhas e problemas institucionais desde sua formação.

Este regime, inicialmente constituído pela Convenção de 1951, veio a sofrer modificações na década seguinte. Durante os anos 1960, novos fluxos de refugiados emergiram na África e na Ásia, decorrentes dos movimentos de descolonização nesses continentes, atestando que essa questão não se restringia ao contexto da Segunda Guerra Mundial e tampouco à Europa. No cenário da confrontação bipolar, tanto os países do bloco ocidental quanto os do bloco soviético buscaram exercer influência sobre os novos Estados que se formavam. Ao mesmo tempo, o ACNUR passou a se voltar para o mundo em desenvolvimento, onde despontavam grandes fluxos de deslocados. Além do confronto Leste-Oeste, as relações no eixo Norte-Sul

WILLIGEN, Loes (Ed.) The refugee convention at fifty: a view from forced migration studies. Lanham; Oxford: Lexington books, 2003. p. 9-21.

${ }^{45}$ GOODWIN-GILL, Guy. Migration: international law and human rights. In: GHOSH, Bimal (Ed.). Managing Migration: time for a new international regime? Oxford: Oxford University Press, 2000.

${ }^{46}$ LOESCHER, Gil. UNHCR and the erosion of refugee protection. Forced Migration Review, Oxford, v.10, p. 28-30, 2001c.

${ }_{47}$ ALEINIKOFF, op. cit., 1995.

${ }^{48}$ Exemplos nesse sentido proliferam, com a proibição de navios transportando potenciais solicitantes de refúgio, provenientes de países da África, atingirem o continente europeu (especialmente, territórios italianos, como a ilha de Lampedusa, gregos e espanhóis), sendo interceptados em altomar. Ver: UNCHR. Desperate journeys: refugees and migrants arriving in Europe and Europe's borders. January - August 2018. Disponível em:

$<$ https://data2.unhcr.org/en/documents/download/65373\# ga=2.203606288.1263638033.1537281666 $-347437977.1517503764>$. Acesso em: 15 set. 2018. 
passavam a impactar o tratamento dado à questão dos refugiados no cenário internacional $^{49}$.

Como a Convenção de 1951 havia sido limitada temporalmente e apresentava a possibilidade de ser restringida também geograficamente, não podia ser aplicada aos novos deslocamentos, deixando africanos e asiáticos descobertos por esse sistema de proteção internacional. A necessidade de se alterar o texto da Convenção decorreu, novamente, dos interesses defendidos pelos atores envolvidos, seja pelos países ocidentais, que se interessavam pelos refugiados provenientes das ex-colônias, seja pelo Alto Comissário, que advogava a ampliação da definição de refugiado ${ }^{50}$. Optou-se, então, por elaborar um instrumento internacional independente, embora relacionado com a Convenção. Isso porque o processo de emenda, que exigia a convocação de uma conferência internacional com todos os Estados-parte da Convenção, seria mais demorado ${ }^{51}$.

O Protocolo sobre o Estatuto dos Refugiados, aprovado em 1967, procurou resolver os problemas gerados pelas duas limitações da Convenção, modificando a definição de refugiado. Colocava-se fim à reserva temporal, ao mesmo tempo em que os Estados que se comprometessem com as obrigações da Convenção ao aderir ao Protocolo ficavam impossibilitados de adotar a reserva geográfica. Era uma forma de sanar essa restrição, fazendo com que os novos Estados que passassem a se comprometer com a questão dos refugiados pudessem receber pessoas oriundas de qualquer parte do mundo ${ }^{52}$. De outro lado, outras lacunas presentes na Convenção não foram supridas pelo novo instrumento, dentre elas, como se processaria a recepção dos refugiados e o processo de elegibilidade referente à concessão do estatuto de refugiado pelos países-membros.

Além disso, diferentemente do regime de direitos humanos (seja o internacional, sejam os regionais ${ }^{53}$ ), o regime internacional de refugiados não previu

\footnotetext{
${ }^{49}$ Ibidem. Idem. Beyond Charity: international cooperation and the global refugee crisis. New York: Oxford University Press, 1996.

${ }^{50}$ HARRELL-BOND, op. cit., 1996.

${ }^{51}$ ACNUR, op. cit., 2000.

52 Ver artigo $1^{\circ}$ do Protocolo de 1967. ACNUR, op.cit., 1996, p. 85-86.
} 
mecanismos para receber petições individuais ou comunicações interestatais ${ }^{54}$. Seguindo novamente o regime de direitos humanos, a temática dos refugiados foi abordada por três perspectivas de regiões distintas: a africana (pautando-se pela Convenção da Organização de Unidade Africana de 1969), a latino-americana (tendo com eixo central a Declaração de Cartagena de 1984) e a europeia (estruturada em torno da Convenção de Dublin, Acordo de Schengen, além de diretivas e regulações da atual União Europeia). Ao contrário dos regimes regionais de direitos humanos, o regime regional de refugiados pioneiro foi o africano e a versão europeia é considerada não tão avançada em relação aos outros dois, que buscaram expandir a definição de refugiado contida na Convenção de $1951^{55}$.

Outro ponto problemático identificado por Loescher é a ausência de uma efetiva articulação entre os dois regimes dentro do sistema ONU. Não existe, por exemplo, um órgão de monitoramento - como um comitêt ${ }^{56}$ específico para analisar questões relativas a refugiados - que poderia ter sido instituído pela Convenção de 1951 ou pelo Protocolo de $1967^{57}$. Como este grupo de deslocados forçados especificamente não teve um lugar de destaque pelos organismos encarregados dos

\footnotetext{
${ }^{54}$ GORLICK, Brian. Human Rights and Refugees: enhancing protection through international human rights law. New Issues in Refugee Research, n. 30, Geneva UNHCR, 2000.

55 JAEGER, op. cit., 2003; ALEINIKOFF, op. cit., 1995; LOESCHER, The UNHCR and world politics: state interests vs. institutional autonomy. International Migration Review, New York, v. 35, n. 1, p. 3356, 2001b.

${ }^{56}$ Vale lembrar que a Convenção sobre a proteção de todos os trabalhadores migrantes e dos membros de suas famílias adotada em 1990, entrando em vigor apenas em 2003, instituiu um comitê específico para monitorar direitos dos migrantes (não tendo sido por este abarcados os refugiados). Contudo, esta convenção se destaca pela baixa adesão de Estados-membros (Ver: PIOVESAN, op. cit., 2012; para consultar o quadro atual de ratificações: http://indicators.ohchr.org/).

${ }^{57}$ Atualmente, é possível que solicitantes de refúgio ou refugiados que tiverem seus direitos violados acessem órgãos do sistema ONU, como comitês criados por diversas convenções e protocolos, ou dos regimes regionais (Comissão Interamericana, Comissão Africana e Corte Europeia) cf. GORLICK, 2000. No sistema ONU, em 1999, foi criado um relator especial sobre direitos humanos dos migrantes (ver: https://www.ohchr.org/EN/Issues/Migration/SRMigrants/Pages/SRMigrantsIndex.aspx). Poucos anos depois, em 2004, estabeleceu-se um relator especial sobre pessoas deslocadas internamente (ver: https://www.ohchr.org/en/issues/idpersons/pages/idpersonsindex.aspx). Não obstante algumas questões relativas a solicitantes de refúgio e refugiados possam ser cobertas pelo mandato do relator especial sobre direitos humanos dos migrantes, poderia ter sido criada uma relatoria própria sobre refúgio - ou asilo em sentido mais amplo -, direcionada a este grupo em particular, tal qual ocorreu com os deslocados internos. Há vários relatores temáticos atualmente operando no sistema ONU: https://spinternet.ohchr.org/ Layouts/SpecialProceduresInternet/ViewAllCountryMandates.aspx?Type $=$ TM. Argumentamos, assim, seguindo Loescher (2001a), que estes regimes poderiam ter sido mais integrados desde sua gênese e poderiam ter sido criados mecanismos especificamente voltados a refugiados para conferir maior eficácia à proteção e garantia de seus direitos.
} 
direitos humanos, segundo o autor, os mecanismos de fiscalização existentes não são considerados eficazes para protegê-los ${ }^{58}$.

\section{Relações entre os regimes de direitos humanos e de refugiados}

De um espectro mais amplo, a ideia de resguardar direitos frente a Estados violadores ou omissos e cunhar garantias mínimas atinentes à dignidade humana despontavam como fundamentais no mesmo processo histórico que marca a institucionalização destes regimes. Vimos também que, tal qual a Declaração, a Convenção seguiu o entendimento de que direitos humanos devem ser interpretados primordialmente como direitos civis e políticos individualizados a partir de uma concepção universalista.

É inegável que a Convenção organizou uma categoria até então definida segundo critérios pouco claros e balizada por instrumentos jurídicos pontuais, estabelecidos de forma ah doc. Importa mencionar que, antes da estruturação deste regime, a determinação da condição de refugiado estava atrelada ao pertencimento a uma coletividade. A título de ilustração, eram reconhecidos como refugiados os palestinos deslocados de sua terra natal, os judeus deslocados do norte da África e do Oriente Médio, os russos e armênios deslocados após a Revolução de $1917^{59}$ ou outros grupos de indivíduos ${ }^{60}$. Uma mudança fundamental emergiu com a Convenção: a ênfase passou a ser dada à perseguição sofrida de forma individual.

Interessa analisar também os cinco componentes atribuídos como os principais motivos que marcam o "fundado temor" da perseguição, a saber, a nacionalidade, a raça, a religião, a filiação a grupo social ou a opinião política. Cada um deles está previsto na Declaração Universal de Direitos Humanos de 1948 e

\footnotetext{
${ }^{58}$ LOESCHER, op. cit., 2001a.

59 Acordo sobre Refugiados Russos e Armênios de 1928, não vinculante, relativa ao direito dos refugiados ao trabalho para acessar os tribunais e proteção contra expulsão.

GLYNN. Irial. The genesis and Development of Article 1 of the 1951 Refugee Convention. Journal of Refugees Studies. v. 25, n. 1, p. 134-148, 2011.

${ }^{60}$ Os norte-coreanos e outros deslocados em função da Guerra de 1950 também estavam envolvidos nesse debate. A posteriori, foram criadas a UN Relief and Works Agency for Palestinian Refugees (UNRWA) e a UN Korean Reconstruction Agency (UNKRA).
} 
categorizados pela literatura especializada ${ }^{61}$ como direitos civis ou políticos. Atribuise a esse fato a imagem da Convenção como um tratado "humanitário" que formalizou uma categoria de refugiado "político". Isso porque privilegiou-se o deslocamento de pessoas motivado por guerras - tanto assim que situações como desastres naturais não foram contempladas pela definição "clássica"62. Não obstante novas definições regionais ${ }^{63}$ tenham sido criadas com o intuito de ampliar esta concepção sobre a categoria de refugiado, a Convenção de 1951 ainda é o instrumento internacional vigente para lidar com esta temática em nível global ${ }^{64}$.

Resgatando as discussões sobre os contornos que assumiriam a definição de refugiado, vale ressaltar o posicionamento dos EUA, que conseguiram estreitar a proposta do projeto inicial, fazendo-o valer frente a outras visões essencialmente diferentes (a definição francesa se assentava na tradição republicana do direito ao asilo e a inglesa enfatizava necessidade de salvaguardar todas as pessoas desprotegidas). Ao contrário do que desejavam os outros países aliados, os EUA optaram por restringir esta categoria jurídica como uma forma de evitar um alto comprometimento financeiro em relação ao ACNUR. A interpretação estadunidense vingou no Comitê ad hoc estabelecido para elaborar a definição da Convenção de 1951, incluindo apenas as vítimas de eventos anteriores à Segunda Guerra Mundial, as vítimas do nazismo e do regime falangista na Espanha, assim como as vítimas de eventos ocorridos na Europa desde o início da Segunda Guerra até de 1 de julho de $1950^{65}$.

O entendimento compartilhado fundante da Convenção de 1951 resulta, portanto, sobretudo da liderança estadunidense, articulando uma frente ocidental para desenhar os limites da nova categoria jurídica. Sua dimensão humanitária não se amparava somente na concepção de que os seres humanos foram dotados de valor e dignidade e sobre os quais se devia vigilância internacional contínua, mas

\footnotetext{
${ }^{61}$ Vide autores já citados neste texto: Alves, 1995; Comparato, 2013; Piovesan, 2012.

${ }^{62}$ GLYNN, op. cit, 2011.

63 Já citamos que ambos documentos chave dos regimes regionais africano e latino-americano (Convenção da OUA de 1969 e Declaração de Cartagena de 1984, respectivamente) se notabilizaram por avançar os significados conferidos à categoria "refugiado", cunhando as chamadas "definições ampliadas" em relação à "definição clássica".

${ }_{64}$ REIS; MOREIRA, op. cit., 2010.

${ }^{65}$ GLYNN. Irial. The genesis and Development of Article 1 of the 1951 Refugee Convention. Jounal of Refugees Studies. v. 25, n. 1, p. 134-148, 2011.
} 
também pelo fato de que estes aspectos estão anunciados, a priori, no reconhecimento da singularidade humana constante da Declaração Universal. Contudo, ao categorizar o refugiado apenas como político, outras tantas graves situações de violações de direitos humanos ficaram descobertas por este regime ${ }^{66}$.

O refugiado foi compreendido, assim, como um indivíduo que busca proteção diante da omissão ou repressão do Estado de origem ou pelo receio fundado de a este retornar. A dimensão política se encontra fundamentalmente calcada na existência histórica de Estados violadores de direitos, forçando o deslocamento de seus próprios nacionais ou residentes (no caso de apátridas). A edificação desse regime internacional esteve, assim, fulcralmente associada aos contornos delimitados pelos direitos civis e políticos, em detrimento dos direitos sociais, econômicos e culturais ${ }^{67}$.

O teor individualista no núcleo central da definição clássica igualmente secundariza a importância de outros direitos, tidos como coletivos, para a realização plena da dignidade humana. Pode-se citar a saúde, como também o direito à habitação com o devido saneamento básico, além do usufruto de uma alimentação saudável, permanente e em quantidade suficiente. São direitos também tidos como inalienáveis à pessoa humana, mas não garantidos pela Convenção de 1951 ou pelo Protocolo de 1967.

Em relação aos direitos econômicos, sociais e culturais por esta especificados, o trabalho digno e remunerado constitui um direito econômico essencial, comumente cerceado sobretudo aos solicitantes de refúgio por legislações nacionais, que exigem a posse de documentação para o seu exercício. O mesmo pode se afirmar em relação ao acesso à educação pública, sem contar as enormes dificuldades frente à moradia digna e em segurança. Direitos culturais são, ainda, fundamentais em termos da realização humana, contudo muitos Estados receptores obstaculizam o exercício da liberdade comunitária e religiosa dentro de suas jurisdições, colocando em xeque o princípio de não-discriminação. ${ }^{68}$

\footnotetext{
${ }^{66}$ GLYNN, op. cit., 2011.

${ }^{67}$ GLYNN, op. cit, 2011.

${ }^{68}$ REIS, op.cit, 2002.
} 
Ainda que se considere o status predominante dos direitos civis e políticos sobre o estatuto do refúgio, permanecem igualmente grandes desafios para concretizá-los em âmbito nacional. Concebendo o sufrágio como direito político por excelência, esbarra-se em sua concretização pelo entendimento de que a nacionalidade é condição indispensável para o pleno exercício da cidadania. Com efeito, há Estados que consentem apenas a nacionais (ou aqueles que passaram pelo processo de naturalização) votar e, especialmente, ser votados. Quando este direito é permitido, há limites impostos pelo status migratório (é preciso ser residente permanente e-ou viver no país por um período considerável) e frequentemente pode ser exercido apenas em nível local (ou seja, por meio de eleições municipais) ${ }^{69}$, a despeito das decisões mais relevantes tomadas em relação aos migrantes se darem na esfera nacional. ${ }^{70}$ Ademais, embora a Declaração Universal de 1948 explicite que todo ser humano tem direito à liberdade de reunião e associação pacífica (Art. 20 §1), o exercício desse direito associativo não raro é negado aos refugiados. A Convenção de 1951, por outro lado, prevê o tratamento igualitário quanto ao direito de associação circunscrito tão-somente às associações sem fins políticos e lucrativos e aos sindicatos profissionais. O direito ao voto, portanto, sequer é enunciado na Convenção - possivelmente em razão da perspectiva voltada à soberania nacional e ao entendimento de que somente os nacionais poderiam exercê-lo.

Uma disposição expressamente inscrita tanto na Declaração Universal quanto na Convenção diz respeito ao impedimento de detenção arbitrária, extensível ao refugiado que se encontre na fronteira ou no território estrangeiro. A proteção a este tipo de sanção deve se dar ainda que o indivíduo se encontre sem documentos (Art. 9 da DUDH e Art. 31 da Convenção). É comum, todavia, a infração desta norma nos espaços fronteiriços dos países do Norte Global, particularmente nos EUA e na Europa Ocidental, que compartilham de uma política

\footnotetext{
${ }^{69}$ Apenas para citar um exemplo, no Brasil, atualmente, tramita a Proposta de Emenda Constitucional n. 25/2012 a fim de conceder direito ao voto nas eleições municipais a estrangeiros residentes no país. Consultar: https://www12.senado.leg.br/noticias/materias/2017/06/14/estrangeiros-residentesno-pais-poderao-participar-em-eleicoes-municipais

${ }^{70}$ CHELIUS, Leticia Calderón. O que há por trás do direito ao voto dos emigrantes internacionais? Teoria, História e Cidadania demandante. Contexto Internacional, Rio de Janeiro, v. 33, n. 1, p. 231250, 2011.
} 
migratória altamente restritiva seguindo uma agenda de securitização da imigração internaciona $^{71}$. Em países desta região, solicitantes de refúgio são sistematicamente presos em centros de detenção, tendo cerceados, assim, o direito de livre circulação, e, não raro, são deportados sem acesso adequado à assistência jurídica $^{72}$. A Convenção ainda dispõe sobre a concessão de documento de identidade ao refugiado que se encontre sem documento de viagem válido, contudo, os mecanismos de que se valem controles migratórios incluem a retenção do passaporte (Art. 27 da Convenção). A partir disso, abrem-se precedentes para a aplicação de métodos degradantes àqueles que não portam documentação em território estrangeiro. Levando a cabo a segurança sobre suas próprias fronteiras, países recorrem a arbitrariedades que se desdobram no não cumprimento de inúmeros outros direitos ${ }^{73}$.

Destes, pode-se ressaltar o direito a uma audiência justa e pública e ao fácil acesso aos tribunais nacionais, previstos no artigo 10 da DUDH e no artigo 16 da Convenção. A DUDH, para além do disposto inicial, preconiza que se deve conceder a condição de plena igualdade sob uma audiência justa e pública por um tribunal independente e imparcial para decidir sobre o fundamento de qualquer acusação criminal. É ainda mais problemático que, pela inobservância desses direitos dentro dos limites previstos, ocorra a afronta da presunção de inocência de forma incisiva. $O$ artigo $11 \S 1^{\circ}$ da Declaração Universal estabelece que todo ser humano é inocente até que a culpabilidade seja comprovada, nos limites da lei, em julgamento público e no qual tenha sido garantida sua ampla defesa.

Diante dos pontos acima levantados, das conexões e das inflexões que os regimes internacionais de direitos humanos e de refugiados mantêm, depreende-se

\footnotetext{
${ }_{71}^{71}$ REIS, op.cit, 2002. REIS; MOREIRA, op. cit., 2010.

${ }^{72}$ Para compreender a atual política estadunidense, ver: PIERCE, Sarah; BOLTER, Jessica; SELEE, Andrew. US Immigration Policy under Trump: deep changes and lasting impacts. Migration Policy Institute, July 2018. Disponível em: <https://www.migrationpolicy.org/research/us-immigration-policytrump-deep-changes-impacts $>$. Acesso em: 15 set. 2018.

Para entender sobre violações de direitos no âmbito da União Europeia, ver: BREEN, Abuses at Europe's borders. Forced Migration Review, Oxford, n. 51, p. 21-23, 2016. Disponível em: $<$ http://www.fmreview.org/sites/fmr/files/FMRdownloads/en/destination-europe/breen.pdf $>$.Acesso em: 15 set. 2018.

Para maiores informações sobre centros de detenção - destacando que a Austrália se marca por adotar tal prática a partir de acordos bilaterais com ilhas do pacífico - consultar o Global Detention Project em: <https://www.globaldetentionproject.org/about-the-gdp>. Acesso em: 15 set. 2018.

${ }^{73}$ Vide referências citadas acima, nas duas notas anteriores.
} 
que a concepção individualista e liberal marcante na ordem internacional no pósguerra corroborou também para a manutenção da tendência hierarquizante dentre os direitos humanos. Com efeito, a centralidade dos direitos civis e políticos, identificada na Declaração Universal transbordou para a Convenção de 1951. Este aspecto constrange a potencialidade de efetivação do regime internacional de refugiados, uma vez que os Estados são levados a privilegiar a proteção destes direitos - relegando os demais a segundo plano - , estabelecendo uma responsabilidade "primeira" concebida desde a Declaração Universal de 1948 frente aos direitos dos refugiados.

\section{Reflexões finais}

O presente estudo buscou demonstrar que a construção da Convenção de 1951 se ancorou em uma definição nuclear de direitos civis e políticos, os quais já estavam previstos na Declaração Universal de Direitos Humanos de 1948 e foram, em larga medida, por esta priorizados frente aos direitos econômicos, sociais, culturais. Dada a relevância estratégica dos EUA e países ocidentais no momento de institucionalização de um regime internacional referente aos refugiados, a Convenção buscou delinear em termos restritos que refugiados e apátridas seriam aqueles perseguidos (ou ameaçados de perseguição) em função de nacionalidade, religião, raça, opinião política ou pertencimento a determinado grupo social. Assim se marcou, sobretudo, a primordialidade de direitos tidos como civis e políticos no bojo da Convenção de 1951, o que, ao fim e ao cabo, limitou a responsabilidade estatal frente à garantia dos demais direitos que compõem o que se entende por fundamentais ${ }^{74}$.

Vale ressaltar que mesmo com a definição da condição jurídica de refugiado, diante da qual todos os Estados estariam compromissados, a Convenção de 1951 buscou favorecer a perspectiva tradicional de soberania estatal sobre o refúgio. Tanto se fez presente essa perspectiva que o direito ao asilo não se tornou imperativo. Com efeito, a proteção aos refugiados fica a cargo de mecanismos

${ }^{74}$ ALVES, op.cit, 1995. GLYNN, op.cit. 2011. 
burocráticos criados pelo Estado - muito mais do que pela Organização das Nações Unidas. Assim se cunhou uma visão ocidental sobre os direitos humanos dos refugiados, e, ao mesmo tempo, a implementação destes permanece em grande medida atrelada à vontade soberana dos Estados receptores e de trânsito ${ }^{75}$.

Em relação ao regime internacional de direitos humanos, é notória a contribuição da DUDH como instrumento ideal que originou todo o sistema de proteção conhecido atualmente. Entende-se como desdobramento fundamental não apenas a elaboração dos pactos internacionais e outras convenções sobre temáticas diversas relacionadas a direitos humanos, como também os comitês criados decorrentes de tais instrumentos. Igualmente se revela de extrema importância a consolidação da Convenção de 1951 como instrumento diretivo em matéria de proteção aos refugiados em âmbito global.

Sustentou-se, ao longo do texto, que a conformação do regime internacional dos refugiados passou por disputas politicas e de ideias entre Estados, particularmente os ocidentais, que conseguiram de fato fincar as bases do regime sobre valores liberais, seguindo a orientação trilhada pelo regime de direitos humanos. Sendo assim, ambos os regimes incorporaram um forte caráter liberal, ocidental, especialmente eurocentrado, e individualizado, muito embora pretendesse lançar ênfase à universalidade, tida como inerente à discussão sobre direitos humanos e, consequentemente, sobre pessoas em situação de refúgio.

Loescher estressa que a ineficácia do regime internacional de refugiados ocorre, sobretudo, pela inexistência de uma autoridade supranacional capaz de compeli-los a cumprir as regras estabelecidas. Ao reforçar a lógica soberana estatal, reafirmando terem os Estados a competência primária para lidar com a questão dos refugiados, este regime acaba por falhar em seu propósito de conduzir a gestão internacional desta problemática ${ }^{76}$. Embora a Convenção de 1951 tenha estabelecido o Alto Comissariado das Nações Unidas para Refugiados como órgão com responsabilidade para proteger este grupo de migrantes internacionalmente forçados, a inflexão identificada no regime de refugiados se refere à escassez de

\footnotetext{
${ }^{75}$ REIS; MOREIRA, op. cit, 2010.

${ }^{76}$ LOESCHER, op. cit, 1996.
} 
mecanismos institucionais para monitorar a atuação dos Estados e pressioná-los a adotar determinadas condutas frente aos refugiados.

Vale aqui lembrar que o regime internacional referente aos refugiados tampouco o de direitos humanos previram, em sua gênese, a criação de órgãos específicos para analisar violações de direitos assegurados aos refugiados ${ }^{77}$. Inexiste, assim, um mecanismo próprio de monitoramento dentro do sistema ONU para fiscalizar a equalização entre a Convenção de 1951 (modificada pelo Protocolo de 1967) e as respostas adotadas internamente em relação aos refugiados pelos Estados-membros. Nesse sentido, os desafios que colocam em xeque a eficácia do regime internacional dos refugiados também estão muito relacionados à não articulação devida dessa questão pelas instituições de direitos humanos no âmbito da ONU. Todo o exposto revela uma fragilidade da própria organização internacional, que não envidou esforços suficientes para uma maior integração entre os dois arcabouços criados para lidar com a temática dos direitos humanos dos refugiados. Logo, desde os primórdios, eis o paradoxo constitutivo de ambos os regimes no bojo do sistema ONU.

\section{Referências}

ACNUR. Conference of plenipotentiaries on the status of refugees and stateless persons: summary record of the twenty-first meeting. 1970. Disponível em: <http://www.unhcr.ch/cgi-bin/textis/vtx/print?tbl=PROTECTION\&id=3ae68cdec>. Acesso em: 5 abr. 2005.

. Conference of plenipotentiaries on the status of refugee and stateless persons: summary record of the twenty-second meeting. 1970. Disponível em: <http://www.unhcr.ch/cgi-bin/textis/vtx/print?tbl=PROTECTION\&id=3ae68cde10>. Acesso em: 5 abr. 2005.

Conference of plenipotentiaries on the status of refugee and stateless persons: summary record of the twenty-third meeting. 1970. Disponível em:

\footnotetext{
${ }^{77}$ LOESCHER, op. cit, 2001a.
} 
<http://www.unhcr.ch/cgi-bin/textis/vtx/print?tbl=PROTECTION\&id=3ae68cda10>. Acesso em: 5 abr. 2005.

. Convenção Relativa ao Estatuto dos Refugiados. In: Manual de procedimentos e critérios a aplicar para determinar o estatuto de refugiado. Lisboa: ACNUR.

- Protocolo sobre o Estatuto dos Refugiados. In: Manual de procedimentos e critérios a aplicar para determinar o estatuto de refugiado. Lisboa: ACNUR, 1996.

ALEINIKOFF, Alexander. State-centered refugee Law: from resettlement to containment. In: DANIEL, E. Valentine; KNUDSEN, John Chr (Ed.). Mistrusting refugees. Berkeley; Los Angeles; London: University of California Press, 1995. p. 257-278.

ALVES, José Augusto Lindgren. Direitos Humanos como Tema Global. São Paulo: Perspectiva, 1995.

ANDRADE, José Henrique Fischel de. Breve reconstituição histórica da tradição que culminou na proteção internacional dos refugiados. In: ARAUJO, N.; ALMEIDA, G. A. de (Coord.). O Direito Internacional dos Refugiados: uma perspectiva brasileira. Rio de Janeiro: Renovar. p. 99-125. 2001.

ARENDT, Hannah. As origens do totalitarismo. São Paulo: Companhia das Letras, 1989.

BETTS, Alexander. Protection by persuasion: international cooperation in the refugee regime. Ithaca: Cornell University Press, 2009.

CHELIUS, Leticia Calderón. O que há por trás do direito ao voto dos emigrantes internacionais? Teoria, História e Cidadania demandante. Contexto Internacional, Rio de Janeiro, v. 33, n. 1, p. 231-250, 2011.

COMPARATO, Fabio Konder. A Afirmação Histórica dos Direitos Humanos. São Paulo: Saraiva, 2013.

CONLEY, Marshall. The institutional framework of refugee law and political forces. In: MAHONEY, Kathleen; MAHONEY, Paul (Ed.) Human Rights in twenty-first century: a global challenge. Dordrecht: Kluwer Academic Publications, 1993. p. 629-643. 
DECLARAÇÃO UNIVERSAL DOS DIREITOS HUMANOS. Disponível em <http://unesdoc.unesco.org/images/0013/001394/139423por.pdf> Acessado em 7 de abril de 2018.

DAUVERGNE, Catherine. Challenges to sovereignty: migration laws for the $21 \mathrm{st}$ century. New issues in refugee research n. 92. Geneva: UNHCR, 2003.

HATHAWAY. James. Reconceiving refugee law as human rights protection. Journal of Refugee Studies, Oxford, v. 4, n. 2, p. 113-131, 1991.

FELLER, Erica. The Convention at 50: the way ahead for refugee protection. Forced Migration Review, Oxford, v.10, p. 6-9, 2001.

GLYNN. Irial. The genesis and development of article 1 of the 1951 Refugee Convention. Journal of Refugees Studies, v. 25, n. 1, p. 134-148, 2011.

GOODWIN-GILL, Guy. Migration: international law and human rights. In: GHOSH, Bimal (Ed.). Managing Migration: time for a new international regime? Oxford: Oxford University Press, 2000.

GORLICK, Brian. Human Rights and Refugees: enhancing protection through international human rights law. New Issues in Refugee Research, n. 30, Geneva UNHCR, 2000.

HADDAD, Emma. The refugee in international society: between sovereigns. Cambridge: Cambridge University Press, 2008.

HAMMAR, Tomas. European Immigration policy: a comparative study. In: MESSINA, Anthony; LAHAV, Gallya. The migration reader: exploring politics and policies. Boulder, Colo.: Lynne Rienner Publishers, 2005. P. 235-245.

HARRELL-BOND, Barbara. Refugees and the international system: the evolution of solutions after the second World War. Siirtolaisuus, n. 3, p. 3-18, 1996.

HATHAWAY. James. Reconceiving refugee law as human rights protection. Journal of Refugee Studies, Oxford, v. 4, n. 2, p. 113-131, 1991.

HOBSBAWN, Eric. Era dos extremos: o breve século XX: 1914-1991. São Paulo: Companhia das Letras, 1995. 
HYNDMAN, Jennifer. Managing displacement: refugees and the politics of humanitarianism. London; Minneapolis: University of Minnesota Press, 2000.

JAEGER, Gilbert. Opening keynote address: the refugee Convention at fifty. In: VAN SELM, Joanne; KAMANGA, Khoti; MORRISON, John; NADI, Aninia; SPOLJARVRZINA, Sanja; VAN WILLIGEN, Loes (Ed.) The refugee convention at fifty: a view from forced migration studies. Lanham; Oxford: Lexington books, 2003. p. 9-21.

LOESCHER, Gil. Beyond Charity: international cooperation and the global refugee crisis. New York: Oxford University Press, 1996.

Protection and humanitarian action in the post-cold war era. In: ZOLBERG, Aristide R.; BENDA, Peter M. (Ed.). Global migrants, global refugees: problems and solutions. New York; Oxford: Berghalm books, 2001a. P. 172-205.

. UNHCR and the erosion of refugee protection. Forced Migration Review, Oxford, v.10, p. 28-30, 2001b.

. The UNHCR and world politics: state interests vs. institutional autonomy. International Migration Review, New York, v. 35, n. 1, p. 33-56, $2001 \mathrm{c}$.

MATAS, David. A history of the politics of refugee protection. In: MAHONEY, Kathleen; Mahoney, Paul. (Ed.). Human Rights in the Twenty-First Century: a global challenge. Dordrecht: Kluwer Academic Publishers, 1993. p. 619-628.

MILLER, Mark J. International migration in post-cold war international relations. In: GHOSH, Bimal. Managing migration: time for a new international regime? Oxford: Oxford University Press, 2000. P. 27-47.

MOREIRA, Julia Bertino. Política em relação aos refugiados no Brasil (1947-2010). Tese (Doutorado em Ciência Política) - Instituto de Filosofia e Ciências Humanas, Campinas: UNICAMP, 2012.

; SALA, José Blanes. Migrações forçadas: categorização em torno de sujeitos migrantes. In: JUBILUT, Liliana Lyra; FRINHANI, Fernanda de Magalhães Dias; LOPES, Rachel de Oliveira (Org.). Migrantes Forçad@s: conceitos e contextos. Boa Vista: Editora da UFRR, 2018. P. 15-42. 
ORGANIZAÇÃO DAS NAÇÕES UNIDAS. Universal Periodic Review. [s.n]. Disponível em <http://www.ohchr.org/EN/HRBodies/UPR/Pages/BasicFacts.aspx> Acessado em 7 de abril de 2018.

OKOTH-OBBO, George; O'CONNOR, Courtney Mireille; KJAERUM, Morten; CHANTAVANICH, Spupang. Regional approaches to forced migration. In: VAN SELM, Joanne; KAMANGA, Khoti; MORRISON, John; NADI, Aninia; SPOLJARVRZINA, Sanja; VAN WILLIGEN, Loes (Ed.) The refugee convention at fifty: a view form forced migration studies. Lanham; Oxford: Lexington books, 2003. p. 31-45.

PIOVESAN, Flávia. Direitos Humanos e Justiça Internacional. São Paulo: Saraiva, 2012.

- Direitos Humanos e o Direito Constitucional Internacional. São Paulo: Saraiva, 2013.

REIS, Rossana Rocha. Construindo Fronteiras: políticas de imigração na França e nos Estados Unidos (1980-1988). Tese de doutorado FFLCH/ USP, São Paulo, 2002.

; MOREIRA, Julia Bertino. Regime internacional para refugiados: mudanças e desafios. Revista Sociologia Política, v. 18, n. 37, 2010.

RUGGIE, John Gerard; KRATOCHWIL, Fridrich von. Epistemologia, ontologia y el estudio de los regimes internacionales. Relaciones Internacionales, Madrid, v. 12, p. 171-191, oct. 2009.

SALOMON, Kim. Refugees in the cold war: toward a new international refugee regime in the early postwar era. Lund: Lund University Press; Bromley: ChartwellBratt, 1991.

SHORT, Katherine. Da Comissão ao Conselho: a Organização das Nações Unidas conseguiu ou não criar um organismo de direitos humanos confiável? SUR Revista Internacional de Direitos Humanos, v. 5, n.9, 2008.

Recebido em: 30/04/2018.

Aprovado em: 11/08/2018. 